\title{
ENVIRONMENTAL POLLUTION AND DAMAGE CONTROL THROUGH MANAGEMENT OF LICENSING AT THE REGIONAL LEVEL
}

\section{PENGENDALIAN PENCEMARAN DAN KERUSAKAN LINGKUNGAN MELALUI PENGELOLAAN PERIZINAN DI TINGKAT DAERAH}

\author{
Mulyadi*, Fahrul Siregar**, Inayatullah Abd hasyim*** \\ mulyadi@unida.ac.id
}

(Diterima pada: 01-07-2018 dan dipublikasikan pada: 30-09-2018)

\begin{abstract}
The objectives to be desired in this study are to analyze and assess control to pollution and environmental damage through management of permits in Bogor Regency, and explain administrative claims for business licenses and/or activities that have already been revoked, if the business already has a business license and/or activity is not in accordance with Article 121 of the Environmental Protection and Management Law. One of the instruments in an effort to prevent pollution and environmental destruction is environmental permits, as stipulated in Article 1 point 35 of Law No. 32 of 2009 which is then regulated in Government Regulation No. 27 of 2012 concerning Environmental Permits. In this provision there are two types of permits, namely environmental permits. The research method used is an empirical normative juridical research method with the consideration that the starting point of the research is analysis of legislation governing licensing. The results of this study illustrate that environmental permits are one of the instruments in efforts to prevent pollution or damage to the environment, to realize the goals of environmental protection and management, especially in the use of the environment associated with environmental permits. Implementation and enforcement of permits will affect the pollution and damage to the existing environment. Therefore local governments are required to enforce environmental law in implementing policies or licensing related to the environment, even if various efforts need to be made, including revocation of licenses and use of criminal channels for those who do not heed destruction and pollution.
\end{abstract}

Keywords: Control, Environment, Management of Licensing

\section{ABSTRAK}

Tujuan yang hendak diinginkan dalam penelitian ini yaitu guna menganalisis dan mengkaji pengendalian dan pencemaran dan kerusakan lingkungan melalui pengelolaan perizinan di Kabupaten Bogor dan menjelaskan gugatan administratif izin usaha dan/ atau kegiatan yang sudah dimiliki untuk dicabut, apabila usaha sudah mempunyai izin usaha dan/atau kegiatan tersebut tidak sesuai dengan Pasal 121 Undang-undang Perlindungan dan Pengelolaan Lingkungan Hidup. Salah satu instrumen dalam upaya untuk mencegah pencemaran dan perusakan lingkungan yaitu izin lingkungan, sebagaimana ditetapkan pada Pasal 1 butir 35 UU No. 32 Tahun 2009 yang kemudian diatur dalam Peraturan Pemerintah No. 27 Tahun 2012 tentang Izin Lingkungan. Dalam ketentuan tersebut terdapat dua jenis izin yaitu izin lingkungan hidup. Metode penelitian yang digunakan yaitu metode penelitian yuridis normatif empiris dengan pertimbangan bahwa titik tolak penelitian analisis terhadap peraturan perundang-undangan yang mengatur tentang perizinan. Hasil penelitian ini menggambarkan bahwa izin lingkungan merupakan salah satu instrumen dalam upaya pencegahan pencemaran ataupun kerusakan pada lingkungan hidup, untuk mewujudkan tujuan dari perlindungan dan pengelolaan lingkungan hidup khususnya dalam pemanfaatan lingkungan yang terkait dengan izin lingkungan. Pelaksanaan dan penegakan perizinan akan berpengaruh terhadap

\footnotetext{
* Fakultas Hukum-Universitas Djuanda Bogor, Jl.Tol Ciawi No 1, Kotak Pos 35 Bogor 16770

** Fakultas Hukum-Universitas Djuanda Bogor, Jl.Tol Ciawi No 1, Kotak Pos 35 Bogor 16770

*** Fakultas Hukum-Universitas Djuanda Bogor, Jl.Tol Ciawi No 1, Kotak Pos 35 Bogor 16770
} 
pencemaran dan kerusakan lingkungan yang ada. Oleh karenanya pemerintah daerah dituntut untuk menegakan hukum lingkungan dalam melaksankan kebijakan atau perizinan terkait lingkungan, bahkan jika diperlukan berbagai upaya harus dilakukan termasuk pencabutan izin dan penggunaan jalur pidana bagi yang tidak mengindahkan pengrusakan dan pencemaran.

Kata Kunci : Pencemaran, Lingkungan Hidup, Pengelolaan Perizinan

\section{A. Pendahuluan}

Menurunnya kualitas lingkungan yang dibarengi dengan berkurangnya persediaan sumber daya alam (SDA) dan munculnya berbagai macam permasalahan lingkungan telah menyadarkan pada pentingnya lingkungan dan peran sumber daya alam pada kehidupan manusia di bumi. Keterbatasan lingkungan tidak dapat mendukung jumlah manusia dan mahluk hidup yang tanpa batas. Sehingga dengan demikian perlu pemanfaatan lingkungan hidup yang lebih bijaksana dan selalu berwawasan lingkungan dalam pemgolahan maupun penggunaan lahan yang tersedia.

Apabila alam semesta tidak lagi mampu menampung jumlah manusia dan kegiatannya, maka manusia akan mengalami banyak kesulitan, oleh sebab itu pertumbuhan jumlah penduduk harus dikendalikan termasuk aktivitas manusianya juga dituntut memperhatikan kelestarian lingkungan. ${ }^{1}$ Sehingga dengan demikian kelestarian lingkungan hidup akan dapat terjaga dengan baik tanpa ada masalah-masalah yang merusak lingkungan.

Kemampuan atau potensi pada manusia sebagaimana di atas, tentunya harus dijalankan dengan bijaksana dengan kata lain tidak melanggar hak-hak orang lain sekaligus tidak melanggar hukum positif dalam arti tidak mencemari ataupun merusak lingkungan. Terkait dengan pengelolaan perizinan pada tingkat daerah seperti halnya di Kabupaten Bogor dikelola oleh Dinas

\footnotetext{
1 Pramudya Sunu, Melindungi Lingkungan dengan Menerapkan ISO 14001, PT Gramedia Widiasarana Indonesia, Jakarta, 2001, hlm 7.
}

Lingkungan Hidup (DLH) Kabupaten Bogor. Dinas ini merupakan unsur pelaksana urusan pemerintahan di bidang lingkungan hidup yang dipimpin oleh seorang Kepala Dinas yang berkedudukan dibawah dan bertanggung jawab kepada Bupati Bogor melalui Sekretaris Daerah Kabupaten Bogor.

DLH mempunyai tugas pokok membantu Bupati dalam melaksanakan urusan pemerintahan di bidang lingkungan hidup dan tugas pembantuan, dan fungsinya, yaitu :

a) Perumusan kebijakan di bidang lingkungan hidup;

b) Pelaksanaan kebijakan di bidang lingkungan hidup;

c) Pelaksanaan monitoring, evaluasi, dan pelaporan di bidang lingkungan hidup;

d) Pelaksanaan administrasi dinas;

e) Pelaksanaan fungsi lain yang diberikan oleh Bupati sesuai tugas dan fungsinya.

Dalam pelaksanaannya di lapangan sampai sejauh ini sejauh ini bisa kita rasakan, Bogor yang dikenal sebagai wilayah yang cocok bagi perkebunan saat ini lambat laun sudah berubah peruntukannya menjadi daerah industri. Tidak heran jika ditemui banyak lahan pertanian berganti menjadi lahan industri. Hal tersebut tentunya harus tetap dalam pengawasan dan kontrol pemerintah daerah. Dengan demikian kegiatan atau usaha yang akan dilakukan oleh masyarakat dapat mejaga kelestarian dan konservasi sumber daya alam. Hal ini tentunya akan lebih meningkatkan taraf hidup manusia ke arah yang lebih baik dan bijaksana.

Konsep ekonomi yang berdasarkan kepada konsep industri akan sangat 
beriringan dengan dampak yang akan ditimbulkannya. Jika tidak ditanggapi secara cepat maka lingkungan kabupaten Bogor akan mengalami kerusakan dan pencemaran yang lebih cepat dan banyak permasalahan yang akan menyertainya.

Dalam kajian ini, penulis merumuskan dua identifikasi permasalahan, pertama bagaimana pengendalian pencemaran dan kerusakan lingkungan dikaitkan dengan perizinan di Kabupaten Bogor? dan kedua bagaimana mengajukan gugatan administratif izin usaha terhadap kegiatan yang telah terlanjur memiliki izin agar dapat di cabut?

Jenis Penelitian yang dilakukan yaitu penelitian hukum normatif dengan pendekatan perundang-undangan (statute approach) dan pendekatan konseptual (conceptual approach). ${ }^{2}$ Dengan pendekatan tersebut penulis ingin mendapatkan pengetahuan dari bermacam segi tentang fenomena hukum yang sedang diteliti, yang dicoba untuk dicari jawabannya. ${ }^{3}$

\section{B. Izin Pengendalian Pencemaran Lingkungan Berdasarkan UU Perlindungan dan Pengelolaan Lingkungan Hidup}

Ijin pengendalian pencemaran lingkungan hidup merupakan ijin lingkungan yang dijabarkan dalam Undang Lingkungan Hidup No32 Tahun 2009 pada Pasal 1 butir 35, akan tetapi tidak hanya terbatas pada ijin yang mencakup persyaratan-persyaratan lingkungan yang diberlakukan pada kegiatan yang bisa menyebabkan pencemaran lingkungan, akan tetapi UU juga memerintahkan bahwa semua ijin dibidang pengelolaan lingkungan hidup yang telah dikeluarkan oleh menteri/gubernur/bupati/walikota sebagaimana kewenangannya wajib

\footnotetext{
2 Peter Mahmud Marzuki, Penelitian Hukum, Prenada Media, Jakarta, Indonesia, 2005.

3 Jhonny Ibrahim, Teori dan Metodologi Penelitian Hukum Normatif, Surabaya, 2005.
}

dimasukan ke dalam ijin lingkungan paling lambat 1 tahun sejak UU diberlakukan.

Pengaturan mengenai ijin lingkungan ditetapkan di dalam peraturan Pemerintah Nomor 27 Tahun 2012.

Pengendalian atas pencemaran dan perusakan lingkungan hidup sebagaimana telah dijabarkan di atas, meliputi :

1) Pengendalian Pencemaran Air (PP No. 28 Tahun 2001);

2) Pengendalian Pencemaran Udara (PP No. 41 Tahun 1999, Peraturan Pemerintah Nomor 4 Tahun 2001, Kep.Men LH No. 35 /MenLH.10/1993, Kep. No. 12/MenLH/3/1996, Keputusan Nomor 48/MenLH/11/1996, Keputusan No.49/MenLH/11/1996, Keputusan No. 50/MenLH/11/1996, Keputusan No. 45/MenLH/10/1997, Kep. Kepala BAPEDAL No. 107/Kbapedal/11/1997.

3) Pengendalian Pencemaran Laut (PP No. 19 Tahun)

4) Pengelolaan Bahan dan Limbah Berbahaya dan Beracun (diatur di dalam Gevaarlijke Stoffen Ordonnantie Stb. 1949 No. 337, PP Nomor 7 Tahun 1993, SK Menteri Perindustrian No. 148/M/SK/1985, Undang-undang No. 10 tahun 1997, PP No. 12 Tahun1995).

\section{Pengendalian Pencemaran dan Kerusakan Lingkungan melalui Perizinan di Tigkat Daerah}

Dalam pelaksanaan pembangunan dan pemerintahan, penting dipahami tujuan dan fungsi hukum sebagai sarana pembaruan masyarakat. ${ }^{4}$

\footnotetext{
${ }^{4}$ Tujuan hukum, selain ketertiban adalah tercapainya keadilan. Selanjutnya untuk mencapai ketertiban perlu kepastian hukum dalam kehidupan bernegara, lihat Mochtar Kusumaatmadja, Fungsi dan Perkembangan Hukum dalam Pembangunan Nasional, Bandung, Bina Cipta, hlm. 2-3. Lihat juga Arief Sidharta, Refleksi terhadap Paradigma Ilmu Hukum di Indonesia (Bahan Kuliah Filsafat Hukum pada Program Pascasarjana Unpad, Bandung, 1999, hlm. 1.
} 
Manifestasi hukum sebagai media pembangunan timbul dalam wujud peraturan perundang-undangan yang mengatur bidang kehidupan adalah pengaturan tentang lingkungan UndangUndang No. 32 Tahun 2009. Dalam upaya perlindungan dan pengelolaan lingkungan hidup, salah satu kewenangan pemerintah yaitu mengimplementasikan izin lingkungan. ${ }^{5}$

Izin adalah alat yang kegunaannya ditetapkan oleh tujuan dan mekanisme yang ditetapkan oleh pemerintah. Juga merupakan kewenangan dan hak pemerintah. Jika perizinan hanya dimaksudkan sebagai sumber pendapatan, maka akan memberikan akibat negatif (disinsetif) bagi pembangunan. Di sisi lain, jika mekanisme perizinan dilaksana dengan model-model yang tidak terbuka, tidak ada kepastian hukum, rumit, dan hanya dapat dilaksanakan dengan metode yang tidak sehat, maka perizinan dapat menjadi penghalang bagi pertumbuhan sosial ekonomi di daerah. Baik dan buruknya maksud perizinan sangat ditentukan oleh mekanisme yang ditetapkan dan dilaksanakan. Semakin sederhana, cepat, dan terbuka mekanisme pemberian perizinan, maka akan semakin tinggi peluang perizinan menjadi alat pengendalian pembangunan. Sehingga masyarakat yang ingin mengurus perizinan lingkungan akan lebih mudah dan leluasa untuk melakukan usahanya tanpa harus menunggu lama dalam proses pengurusan perizinan. Dalam hal ini instrumen perijinan perlu mendapat perhatian yang cukup serius dari pemerintah.

Kebijakan dalam bentuk izin harus mencerminkan kebijakan yang sesuai dengan perikehidupan seluruh lapisan masyarakat, sehingga tujuan negara dalam konsep negara kesejahteraan

\footnotetext{
${ }^{5}$ Mochtar Kusumaatmadja, Hukum, Masyarakat, dan Pembinaan Hukum Nasional, Bina Cipta, Bandung, 1995, hlm. 13.
}

(welfare state) yang termaktub dalam Pembukaan Undang-Undang Dasar 1945 alinea ke-4 dapat terwujud.

Konsep negara kesejahteraan berkaitan dengan peranan Hukum Administrasi Negara. $^{6}$ Hukum Administrasi Negara memegang peran yang cukup besar terkait dengan semakin luasnya urusan pemerintahan yang berkaitan dengan kepentingan rakyat banyak dan dituntut partisipasi dalam penyelenggaraan kesejahteraan rakyat. Dalam model negara kesejahteraan, pemerintah dituntut berpartisipasi aktif dalam bidang lingkungan hidup. Hal ini karena bidang ini karena terkait dengan kepentingan rakyat banyak yang luas dan transparansi partisipasi masyarakat dalam pembangunan nasional maupun pembangunan daerah.

Hukum lingkungan menjadi pedoman dalam upaya perlindungan dan pengelolaan lingkungan hidup. Kaidah perlindungan dan pengelolaan lingkungan hidup menjadi pegangan dalam penyelenggaraan perizinan bidang lingkungan hidup. Perizinan mempunyai peranan, yaitu:

1. Sebagai instrumen rekayasa pembangunan. $^{7}$ Pemerintah dapat membuat regulasi dan keputusan yang memberikan dukungan bagi pertumbuhan sosial ekonomi. Demikian juga, ketentuan dan keputusan itu dapat menjadi penghambat dan sumber korupsi dalam pembangunan.

2. Sebagai perangkat hukum yang digunakan oleh pemerintah untuk mempengaruhi masyarakat agar

6 Stellinga sebagaimana dikutip oleh I Gde Pantja Astawa dalam tulisannya, Hubungan Fungsional Antara Hukum, Administrasi Negara dengan UU No. 4 Tahun 1982 tentang Ketentuan Pokok Pengelolaan Lingkungan Hidup dan Pelaksanaannya, dalam buku S.F.Marbun, et.al., Dimensi-Dimensi Pemikiran Hukum Administrasi Negara, UII Press, Yogyakarta, 2001, hlm. 296.

7 Adrian Sutedi, Hukum Perizinan dalam Sektor Pelayanan Publik, Sinar Grafika, Jakarta, 2010, hlm. 193. 
mengikuti cara yang dianjurkannya untuk mencapai tujuan konkret. ${ }^{8}$

3. Sebagai fungsi keuangan, yaitu sumber pendapatan negara. ${ }^{9}$

4. Sebagai fungsi pengaturan, yaitu menjadi alat pengaturan tindakan/prilaku masyarakat. ${ }^{10}$

Izin merupakan persetujuan dari penguasa berdasarkan UU atau PP, untuk pada posisi menyimpang dari ketentuan larangan perundangundangan. ${ }^{11}$

Menurut Pasal 40 UUPPLH, izin lingkungan merupakan persyaratan mendapatkan izin usaha dan/atau kegiatan. Dalam hal perizinan, yang berwenang mengeluarkan izin adalah pejabat administrative. Penegakan hukum dapat dilakukan secara preventif dan dapat juga dilakukan secara represif. Dimana kepada para pelanggar akan dikenakan sanksi hukuman yang cukup berat dan masyarakat tidak akan melakukan pelanggaran lagi.

Upaya tersebut merupakan upaya non penal yang harus didorong sebagai sarana dan prasarana untuk menyelesaikan masalah lingkungan secara dini dan lebih cepat. Sehingga permasalahan lingkungan dapat diselesaikan antar para pihak sehingga tidak perlu melalui jalur pengadilan. Dan para pihak yang bersengketa akan dapat lebih cepat menyelesaikan permasalahan lingkungan dengan upaya mediasi.

D. Pencabutan Izin Usaha Terhadap Kegiatan Usaha yang melakukan pencemaran dan kerurasakan

Proses pembangunan yang dilakukan oleh Bangsa Indonesia harus dilaksanakan berdasarkan prinsip dan asas pembangunan yang berkelanjutan

8 Philipus Hadjon, M. et al. Pengantar Hukum Administrasi Indonesia, Gajah Mada University Press, Yogjakarta, 2005.

9 Adrian Sutedi, Hukum Perizinan dalam Sektor Pelayanan Publik, Sinar Grafika, Jakarta, 2010, hlm. 199.

${ }^{10} \mathrm{Ibid}, \mathrm{hlm} .200$.

${ }^{11}$ M.Spelt dan J.B.J.M.ten Berge, Ibid., hlm. 2. serta pembangunan yang berwawasan lingkungan sebagaimana yang diamanatkan di dalam UUD 1945 Pasal 33 ayat (4). Penggunaan sumber daya alam bagi bangsa Indonesia masih menjadi modal utama pembangunan di Indonesia sekarang inidan masih tetap dibutuhkan untuk yang yang akan datang. Oleh sebab itu, pemanfaatan sumber daya alam tersebut harus dapat dilakukan secara bijaksana dan arif.

Penggunaan sumber daya alam yang dilakukan seharusnya didasari oleh pilarpilar pembangunan yang berkelanjutan, yaitu menguntungkan secara ekonomi, diterima secara sosial, serta dengan konsep ramah lingkungan. Mekanisme pembangunan yang dilaksanakan melalui cara tersebut diharapkan bisa meningkatkan kemakmuran dan mutu kehidupam generasi sekarang dan generasi masa yang akan datang.

Dengan diimplementasikannya asas pembangunan yang berkelanjutan dan pembangunan berwawasan lingkungan dalam penyelenggarakan pembangunan, maka implikasi atas lingkungan yang disebabkan oleh kegiatan-kegiatan pembangunan di evaluasi sejak dini perencanaannya, sehingga langkah pengendalian implikasi tnegatif dan pengembangan implikasi positif bisa dipersiapkan semenjak awal. Alat yang dapat dipergunakan untuk melaksanakan hal tersebut adalah Analisis Mengenai Dampak Lingkungan (AMDAL), Usaha Pengelolaan Lingkungan (UKL), dan Usaha Pemanfaatan Lingkungan (UPL).

Di dalam UU No. 32 Tahun 2009 pada Pasal 22 ditetapkan bahwa setiap usaha dan/atau kegiatan yang berdampak penting terhadap lingkungan hidup wajib memiliki Amdal (Analisis Mengenai Dampak Lingkungan).

Analisis Mengenai Dampak Lingkungan tidak hanya meliputi analisis terhadap unsur biofisik dan kimiawi, akan tetapi juga meliputi unsur sosial ekonomi, sosial budaya, serta kesehatan masyarakat. 
Tujuan penegakan hukum terkait lingkungan yaitu penataan (compliance) terhadap nilai-nilai perlindungan daya dukung ekosistem dan fungsi lingkugan hidup pada umumnya diformalkan kedalam peraturan perundang-undangan, termasuk ketentuan yang mengatur baku mutu limbah atau emisi. Yang pembuangannya harus mengikuti prosedur yang telah ditetapkan oleh pemerintah.

Upaya preventif dalam rangka pengendalian dampak lingkungan hidup perlu dilakukan dengan menggunakan instrumen untuk pengawasan dengan memperhatikan berbagai syarat yang tercantum dalam perizinan. Dalam pencemaran dan kerusakan lingkungan yang sudah terjadi, diperlukan upaya represif seperti penegakan hukum secara efektif, konsisten, dan konsekuen terhadap pencemaran dan kerusakan yang terjadi. Sehingga perlu dikembangkan satu sistem hukum perlindungan dan pengelolaan lingkungan hidup yang jelas, tegas, dan menyeluruh untuk menjamin kepastian hukum sebagai landasan bagi perlindungan juga pengelolaan sumber daya alam (SDA) serta kegiatan pembangunan lain yang turut mendukung upaya pembangunan yang berkelanjutan. Sehingga kelestarian alam semesta akan lebih terjaga.

Pengenaan sanksi administratif seperti pembekuan/ pencabutan izin lingkungan sebagaimana Pasal 79 UUPPLH, dilakukan manakala terdapat pihak yang terganggu kesehatannya akibat pencemaran/perusakan lingkungan dan penanggung jawab usaha tidak melaksanakan paksaan pemerintah (Bestuurdwang).

Paksaan pemerintah tersebut berdasarkan Pasal 80 Undang-undang Perlindungan dan pengelolaan liungkungan hidup, berupa: penghentian sementara, pemindahan sarana, penutupan saluran pembuangan air limbah atau emisi, pembongkaran, penyitaan, penghentian sementara seluruh kegiatan atau tindakan lainnya. Dengan demikian tindakan-tindakan tersebut akan memberikan efek jera kepada para pelakunya.

Bentuk-bentuk Pemanfaatan Lingkungan Hidup di Kabupaten Bogor

a. Digunakan untuk memenuhi kebutuhan hidup manusia, seperti manusia membutuhkan air untuk keperluan minum, memasak, dan mandi.

b. Digunakan untuk industri, seperti industri yang menghasilkan produknya berupa oksigen $(\mathrm{O} 2)$ yang tersimpan di dalam tabung, industri air mineral, industri pupuk organik industri minyak bumi, gas dan lainlain.

c. Digunakan pemerintah sebagai daerah konservasi agar lingkungan hidup tersebut terjaga, seperti adanya suaka alam, suaka margasatwa, taman nasional, kebun binatang, dan hutan lindung.

Beberapa hal yang dapat dilakukan sebagai bentuk upaya pelestarian lingkungan hidup, antara lain sebagai berikut.

a. menghemat penggunaan kertas dan pensil,

b. membuang sampah pada tempatnya,

c. memanfaatkan barang-barang hasil daur ulang,

d. menghemat penggunaan listrik, air, dan BBM, serta

e. menanam dan merawat pohon di sekitar lingkungan rumah tinggal.

Tujuan dari adanya Pemanfaatan Lingkungan Hidup

a) Tercapainya keselarasan, keserasian, dan keseimbangan antara manusia dan lingkungan hidup.

b) Terwujudnya manusia Indonesia sebagai insan lingkungan hidup yang memiliki sikap dan tindakan melindungo serta membina lingkungan hidup.

c) Terjaminnya kepentingan generasi masa kini dan generasi masa depan.

d) Tercapainya kelestarian fungsi lingkungan hidup. 
e) Terkendalinya pemanfaatan sumber daya secara bijaksana.

f) Terlindunginya Indonesia terhadap dampak dari luar yang dapat menyebabkan pencemaran atau kerusakan lingkungan.

Salah satu kewenangan pemerintah dalam rangka pengelolaan lingkungan yang baik adalah dengan menerapkan ijin lingkungan. Ijin hanya merupakan wewenang dan kekuasaan dari pemerintah. Ijin merupakan instrumen pemerintah yang memiliki sifat yuridis preventif dan digunakan sebagai instrumen hukum administrasi negara guna mengendalikan perilaku dan etika masyarakat dalam pemanfaatan lingkungan. Oleh sebab itu, maka fungsi dari sebuah ijin adalah bersifat pencegahan atau preventif, karena di dalam instrumen ijin tidak bisa dilepaskan dengan perintah dan kewajiban yang harus ditaati oleh pemegang ijin.

Selain dari pada itu, bahwa ijin itu berfungsi represif. Artinya ijin dapat berfungsi sebagai alat untuk menanggulangi masalah-masalah lingkungan yang disebabkan oleh kegiatan atau usaha yang dilakukan oleh manusia yang melekat erat dengan dasar perijinan. Hal ini berarti bahwa suatu usaha atau kegiatan yang memperoleh ijin atas pemanfaatan lingkungan hidup, maka dibebani kewajiban untuk melakukan penanggulangan pencemaran atau perusakan lingkungan yang timbul dari aktivitas usaha atau kegiatannya.

Sebuah ijin yang akan dikeluarkan atau diterbitkan, harus memenuhi kriteria legalitas. Artinya bahwa dasar-dasar penerbitan ijin harus memenuhi ketentuan peraturan perundang-undangan.

Ijin lingkungan merupakan alat atau instrumen pemerintah di dalam hukum administrasi guna mempertahankan bentuk pengelolaan lingkungan yang baik. Bermacam-macam perijinan diterbitkan untuk pengelolaan lingkungan, seperti dibidang pertambangan, perindustrian, perdagangan, dan lain-lain. Sistem perijinan adalah sebuah instrumen yang begitu penting dalam upaya pengendalian lingkungan hidup.

Bahwa sifat suatu perijinan lingkungan itu adalah : bersifat yuridis, yaitu salah satu sarana hukum administrasi yang diimplementasikan oleh penguasa atau penyelenggara negara atau tata usaha negara, perijinan merupakan kebijakan penguasa atau pemerintah, tidak ada badan lain di luar penguasa yang dapat atau boleh memberikan perijinan terkecuali pemerintah atau atas kuasa dari pemerintah; bahwa perijinan merupakan kebijakan instrumen yang bersifat pencegahan atau preventif, artinya hanya dimaksudkan untuk mengendalikan lingkungan agar tidak punah atau mengalami penurunan/degradasi kualitas; bahwa sanksi atau akibat hukum dari adanya pelanggaran yang dilakukan adalah di luar paksaan badan.

Bahwa sanksi dari suatu pelanggaran perijinan adalah pencabuatan ijin usaha atau kegiatan, penundaaan perijinan, pembekuan perijinan, adanya denda, atau teguran secara tertulis, dan tidak dalam bentuk paksaan badan.

Yang menjadi dasar hukum untuk memberlakukan perijinan lingkungan di sebagai upaya penegakan hukum administrasi bersumber dari berbagai perangkat peraturan, yaitu : Hinder Ordonantie (S.1926 No. 226); UUPPLH; PP No. 20 Tahun 1990; Peraturan Pemerintah No. 19 Tahun 1994 juncto Peraturan Pemerintah No. 12 Tahun 1995).

Hinder Ordonantie memberikan kewenangan atau kekuasaan kepada Pemerintah Daerah untuk menegakan hukum administrasi melalui perijinan. Peraturan Pemerintah No. 20 Tahun 1990 memberikan wewenang kepada Bupati maupun Gubernur untuk menjatuhkan sanksi administrastif, berupa pengelolaan saluran pembuangan limbah, menghentikan aktivitas atau kegiatan sementara dan pencabutan ijin pembuangan limbah. Peraturan Pemerintah No. 19 Tahun 1994 juncto Peraturan Pemerintah No. 12 Tahun 1995 memberikan kewenangan kepada Badan Pengendalian Lingkungan Pusat untuk menghentikan 
sementara kegiatan sampai dengan ditaatinya perintah atau peraturan.

Undang-undang No. 32 Tahun 2009 juga memberikan kewenangan kepada Gubernur/Kepala Daerah Propinsi untuk melakukanpaksaan pemerintah terhadap pelaku usaha atau kegiatan.

Suatu sistem perijinan lingkungan dihubungkan dengan kewajiban untuk memperoleh Analisis Mengenai Dampak Lingkungan, hal ini berarti untuk dikeluarkannya suatu perijianan lingkungan, maka disyaratkan supaya diperoleh terlebih dahulu yaitu Analisis Mengenai Dampak Lingkungan.

Suatu rencana usaha dan/atau kegiatan yang menurut ketentuan peraturan perundang-undangan yang berlaku, maka diwajibkan untuk melaksanakan analisis mengenai dampak lingkungan hidup, oleh karena itu maka persetujuan atas hasil analisis mengenai dampak lingkungan hidup yang dimaksudkan, maka wajib diajukan bersaan dengan permohonan ijin untuk melakukan kegiatan dan/atau usaha.

Suatu perijinan dihubungkan pula dengan persyaratan-persyaratan dan kewajiban-kewajiban. Terdapat kewajiban yang yang musti dilaksanakan oleh penanggung jawab usaha atau pengusaha, sebelum dokumen ijinnya dikeluarkan oleh pihak yang berwenang. Untuk kemudian pada ijin yang diterbitkan, dicantumkan daftar persyaratan-persyaratan dan kewajiban-kewajiban untuk dipatuhi oleh pihak perusahaan, dan hal ini merupakan alat pengendali bagi pentaatan terhadap peraturan dan ketentuan lingkungan.

Semua perijinan tentang pengelolaan lingkungan hidup dilakukan secara terpadu. Dengan demikian ijin lingkungan yang diterbitkan untuk mengatur secara sekaligus dan komprehensif antara media udara, air, tanah maupun limbah bahan berbahaya dan beracun dilaksanakan di dalam satu kesatuan. Andaikata, dari bermacam perijinan, dimana salah satu dinyatakan telah dicabut, maka secara otomatis kegiatan yang bersangkutan tidak dapat lagi melakukan kegiatan operasional usaha, sebab salah satu dari perijinan tersebut sudah tidak berlaku lagi.

Sistem perijinan yang berkaitan dengan lingkungan adalah ijin tempat atau lokasi usaha. Ijin ini telah diatur di dalam Hinder Ordonantie (HO/Ordonansi Gangguan). Sebagaimana diatur dalam S.1926 No. 226, yang selanjutnya telah diamandemen dengan S.1927 No. 499, S.1940 No. 14 dan 450.

Hinder Ordonantie ini diberlakukan berdasarkan asas konkordansi hukum Belanda ke Indonesia. Di dalam sistem perijinan di Indonesia ssaat ini, undangundang telah memberikan hak pengawasan atau kontrol bagi masyarakat. Di dalam mengeluarkan ijin, setiap instansi yang mengelola penerbitan ijin, selain diwajibkan untuk memperhatikan sistem tata ruang dan pertimbangan-pertimbangan dari para pejabat yang terkait, tetapi juga diwajibkan untuk memperhatikan pendapat atau aspirasi dari masyarakat.

Dengan demikian, maka masyarakat memiliki peran yang penting terhadap sistem perijinan secara nasional. Agar partisipasi masyarakat dapat diikutsertakan, amak dilibatkan ke dalam sistem perijinan yang demikian ini, oleh karena itu maka dianut sistem informasi dan publikasi berbasis masyarakat, yaitu bahwa setiap keputusan ijin usaha dan atau kegiatan, wajib atau harus diumumkan kepada masyarakat.

Selanjutnya, bahwa perijinan dapat dibedakan ke dalam 2 (dua) sifat, yaitu bahwa perijinan diwajibkan atau dihubungkan dengan Amdal, hal ini berarti, terlebih dahulu harua ada Amdal, baru kemudian diterbitkan ijin; kedua, bahwa perijinan yang tidak dihubungkan dengan Amdal. Apabila sebuah kegiatan menurut ketentuan peraturan perundang-undangan yang berlaku diwajibkan menyelenggarakan Amdal, maka dengan demikian Amdal tersebut wajib diajukan bersamaan dengan permohonan ijin untuk melakukan usaha atau kegiatan. Hal demikian dimaksudkan untuk tidak terlalu memberatkan bagi siapa saja yang mengajukan permohoan ijin.

Dihubungkan dengan faktor tata ruang terhadap pemberian ijin, maka 
merupakan suatu hal yang sangat penting. Sebab segi tata ruang mempunyai keterkaitan yang sangat erat dengan model pengelolaan lingkungan. Bahwa pengelolaan lingkungan membutuhkan adanya suatu sistem yang terpadu, yang meliputi kebijakan penataan, pemanfaatan, pengembangan, pemeliharaan, pemulihan, pengawasan, serta pengendaliannya.

Bahwa penataan ruang bertujuan untuk mewujudkan keharmonisan antara lingkungan alamiah dan lingkungan buatan.; untuk mewujudkan keterpaduan penggunaan sumber daya alam dan buatan; meningkatkan penggunaan sumber daya alam dan buatan secara efektip, efisien, serta produktif.

Hal lain lagi yang penting di dalam penataan ruang yaitu mewujudkan perlindungan fungsi dan ruang, mencegah serta mengatasi akibat negatif terhadap lingkungan. Dengan memperhatikan segi tata ruang, maka perijinan terhadap suatu kegiatan atau usaha yang menyangkut kegiatan lingkungan, hanya bisa diberikan jika tidak melanggar sistem tata ruang.

Selain itu faktor pendapat atau aspirasi masyarakat juga teramat penting untuk mengeluarkan ijin. Hal ini berkaitan denga hak setiap warga masyarakat untuk mendapatkan lingkungan hidup yang bersih dan sehat; hak setiap masayarakat untuk ikut berperan serta di dalam pemanfaatan dan pengelolaan lingkungan.

Lebih dari itu adalah bahwa masyarakat berhak atas informasi tentang lingkungan hidup. Dengan demikian, maka adanya faktor pendapat masyarakat di dalam pemberian ijin lingkungan merupakan suatu daripada masyarakat, dengan lain perkataan masyarakat tidak boleh dihalang-halangi di dalam pemberian pendapat atas suatu ijin yang diberikan oleh penguasa atau pemerintah.

Dihubungkannya perijinan dengan pendapat atau partisipasi masyarakat, agar warga masyarakat bisa memberikan sumbangan pemikiran, saran pendapat, serta tanggapan atas suatu rencana kegiatan yang akan dilakukan yang mempergunakan lingkungan. Tentu saja masyarakat bisa mengajukan keberatan terhadap rencana pemberian ijin yang akan dikeluarkan oleh pemerintah, apabila masyarakat menganggap bahwa kegiatan yang akan diberikan ijin tersebut akan merugikan atau merusak lingkungan hidup tempat mereka tinggal dan beraktivitas.

Masyarakat mempunyai hak dan kesempatan yang sama dan seluas-luasnya untuk berperan aktif di dalam perlindungan dan pengelolaan lingkungan hidup. Peran dari masyarakat tersebut dapat meliputi : pengawasan sosial, pemberian saran, pendapat, usul, keberatan, pengaduan, penyampaian informasi ataupun berupa laporan.

Tujuan dari peran serta masyarakat tersebut yaitu : untuk meningkatkan kepekaan dalam perlindungan dan pengelolaan lingkungan hidup, untuk meningkatkan kemandirian, keberdayaan masyarakat, dan kemitraan. Untuk memumbuhkembangkan kemampuan dan ketokohan masyarakat.

\section{E. Kesimpulan}

Berdasarkan pembahasan yang telah dikemukakan diatas, maka dapat disimpulkan sebagai berikut :

1. Pengendalian Pencemaran dan Kerusakan Lingkungan melalui Perizinan di Tigkat Daerah merupakan hal yang mutlak harus dilakukan, karena Izin lingkungan merupakan instrumen atau bentuk otoritas dan monopoli pemerintah dalam menjaga kondisi lingkungan daerahnya agar tetap aman, nyaman tanpa ada pencemaran dan kerusakan lingkungan bukan sekadar sumber pendapatan yang pada akhirnya akan memberikan dampak yang negatif (disinsetif) bagi daerah. Selain itu perizinan berfungsi sebagai sarana yuridis untuk mencegah serta menanggulangi pencemaran dan kerusakan lingkungan. Yang merupakan hal yang sangat penting untuk meningkatkan taraf kehidupan manusia. 
2. Pencabutan izin melakukan usaha terhadap kegiatan usaha yang melakukan pencemaran dan kerurasakan merupakan upaya yang harus didorong sebagai sarana menyelesaikan masalah lingkungan secara dini. Selain penjarngan melalui pemberian izin, upaya preventif lain juga harus dilakukan dengan menggunakan instrumen pengawasan yang ditindak lanjuti dengan upaya represif seperti penegakan hukum secara efektif, konsisten, dan konsekuen terhadap pencemaran dan kerusakan yang terjadi. Jika diperlukan apabila upaya ini tidak atau kurang berhasil, bisa dilakukan penindakan secara pidana. Hal tersebut dilakukan dengan mendayagunakan berbagai ketentuan hukum, baik hukum administrasi, hukum pidana, maupun hukum perdata.

\section{DAFTAR PUSTAKA}

\section{A. BUKU}

Andi Hamzah, Penegakan Hukum Lingkungan, Sinar Grafika Jakarta, 2005.

Adrian Sutedi, Hukum Perizinan dalam Sektor Pelayanan Publik, Sinar Grafika, Jakarta, 2010.

Alvi Syahrin, Ketentuan Dalam UU No. 32 Tahun 2009 Tentang Perlindungan dan Pengelolaan Lingkungan Hidup, Cetakan PT. Sofmedia, 2011.

Bagir Manan. Menyongsong Fajar Otonomi Daerah. Pusat Studi Hukum, FH UIIPustaka Pelajar, Yogyakarta. 2005

Daud Silalahi, Hukum Lingkungan Dalam Sistem Penegakan Hukum Lingkungan Indonesia. Alumni Bandung, 2001.

Helmi, Hukum Lingkungan dan Perizinan Bidang Lingkungan Hidup, Sinar Grafika, Unpad Press, Bandung, 2010.

Munadjat Danusaputro, Hukum Lingkungan Buku I, Binacipta, Bandung, 1985.

N.M.Spelt dan J.B.J.M.Ten Berge, disunting Philipus M.Hadjon, 1993, Pengantar Hukum Perizinan, Penerbit Yuridika, Surabaya.

Peter Mahmud Marzuki, Penelitian Hukum, Prenada Media, Jakarta, Indonesia, 2005.

Pramudya Sunu, Melindungi Lingkungan dengan Menerapkan ISO 14001, PT Gramedia Widiasarana Indonesia, Jakarta, 2001.

Ridwan, HR., Hukum Administrasi Negara, UII press, Yogyakarta, 2003.

Satjipto Rahardjo, Ilmu Hukum, (Bandung: PT. Citra Aditya Bakti, 1999).

Suparni, Penegakan Hukum Lingkungan, Jakarta, 1994.

Supriadi, Hukum Lingkungan di Indonesia: Sebuah Pengantar, Sinar Grafika, Jakarta, 2008. 


\section{B. PERATURAN PERUNDANG-UNDANGAN}

UUD 1945

UU No. 32 Tahun 2009 tentang Perlindungan dan Pengelolaan Lingkungan Hidup.

UU No. 27 Tahun 2012 tentang Izin Lingkungan.

\section{ARTIKEL ELEKTRONIK}

- http://taufiqnugroho.blogspot.com/2009/02/penegakan-hukum-lingkungan.html diakses pada tanggal 9 April 2016

- Alvi Syahrin, Isu Hukum : Izin Lingkungan dan Penerapan Sanksi Administratif Berdasarkan UUPPLH, http://.com/izin-lingkungan-administratif.html. diakses tanggal April 2016.

- Alvi Syahrin, Izin Lingkungan dan Penerapan Sanksi Administratif Berdasarkan UUPPLH Terhadap Usaha/Kegiatan yang Telah Memiliki Izin Usaha/Kegiatan, http://alviprofdr.blogspot.com/2013/03/izin-lingkungan-dan-isuhukumnya.html. diakses pada tanggal Maret 2016. 